\title{
Philosophy of Education in Indonesia: Theory and Thoughts of Institutionalized State (PANCASILA)
}

\author{
Dwi Siswoyo ${ }^{1}$ \\ ${ }^{1}$ Yogyakarta State University, Indonesia \\ Correspondence: Dwi Siswoyo, Yogyakarta State University, Indonesia. E-mail: dwi.siswoyo@yahoo.co.id
}

Received: August 1, 2013 Accepted: August 16, 2013 Online Published: August 30, 2013

doi:10.5539/ass.v9n12p136

URL: http://dx.doi.org/10.5539/ass.v9n12p136

\begin{abstract}
This study proposes for the urgency of the Ideal Image of Indonesian People (Citra Ideal Manusia Indonesia) in the Philosophical Constructs of Pancasila National Education in the Indonesian Philosophical Construct of National Education. Indonesian Philosophical Construct of National Education is expected to be a dynamic and contextual frame in the development of theory, praxis education system and nationality, as well as a reference in solving problems of national education from a philosophical point of view. This type of study is a philosophical study, namely hermeneutical studies. The objective of this study is the works of "founding fathers" (especially Bung Karno) of Pancasila, and the works of Ki Hajar Dewantara, Notonagoro and Driyarkara about the Pancasila philosophy, about education and nationality, and a dialogue with the works of other relevant figures, and a reflection on the various national education philosophical issues. The methodology used is hermeneutical dialectic. The results of the study show the Urgency Pancasila as a basic philosophy for Indonesian nation. The ideal image of Indonesian human is the central focus of development and implementation of Indonesian national education system. The concept of the ideal image can be constructed by the Philosophical Construct of Pancasila National Education. Pancasila was propagated by Bung Karno and contains the values of the ideal and quite remarkable superiority as the basic philosophy of the state which to date its earnest practice has not been matched in various fields of life. Pancasila need to be supported with efforts by the construct of national education philosophy of Pancasila, and the ideal image of the Indonesian people.
\end{abstract}

Keywords: Pancasila, philosophy of education, national, philosophy

\section{Introduction}

In the latest decade, it is observed in various fields including education that technical thinking has replaced basic and comprehensive thinking. In addition, various education reform efforts seem more likely to be patchy and partial, disintegrative, not firmly built as a unity to achieve the goals of national education. In order to implement national education, especially in guiding the reform efforts of national education, there is a need for a philosophical reference, i.e., Philosophical construct of Pancasila National Education, to provide the way of figuring out the ideal image of Indonesian people who may be a reference to the educational attainment of nationhood.

Notonagoro (Dwi Siswoyo, 2013) affirms that the characteristical feature of National Education is the development of ability/skillfulness and personality that are united, organized, harmonized and dynamic (sifat $d w i$ tunggal pendidikan kebangsaan ialah pengembangan keperibadian dan kemampuan/keahlian, dalam kesatuan organis harmonis dan dinamis). Therefore, it should always be consolidated so that Indonesia will be a developed nation, dignified, and have a strong identity and dynamic, and able to face the challenges nationally and globally. Education is a human phenomenon (Driyarkara, 1980), that education is a phenomenon of human nationality Indonesia. The goal of education is to improve man as a man (Dwi Siswoyo, 2013), to humanize Indonesian man who can implement and develop his life in the encounter and interaction with others and the world, as well as in his relationship with God.

The development of Indonesian National Education Philosophy, that is Philosophy of Pancasila National Education, is hoped to play a role as a contextual and dynamic source for theory and ptactice of national education in Indonesia. The formal objective of National Education Philosophy is to radically analyze all of the phenomena in education and those which are related to them from a comprehensive and integrated perspective. An ideal form of National Education refers to the development of ability/skillfulness and personality that are 
united, organized, harmonized and dynamic (dalam kesatuan organis harmonis dan dinamis) in ensuring a complete human development in Indonesia.

The development of National Education Philosophy based on Pancasila has to be rejuvenative. Rejuvenation means regeneration ("pemudaan kembali") (Sukarno, 1990: 187-188). Rejuvenation in this paper refers to the National Education that has to consolidate new spirit, vision, invention and innovation as being sourced from rejuvenated values from Pancasila based on confidence and implementation of Philosophy of Pancasila National Education. The development of Philosophy of Pancasila National Education can be carried out through the approach of eclectic-incorporative-harmony-dynamic ("eklektik-inkorporatif-harmonis-dinamis") (Notonagoro, 1973 who cited eclectic-incorporative ("eklektis-inkorporasi") approach). Eclectic refers to the act of selecting the best approach from various sources (KBBI, 2012); Eugene Ehrlich, et.al, 1986: 272). Incorporated means to include as a part (Eugene Ehrlich, et al, 1986: 446) or to combine into a unified whole (Webster's Dictionary, 1993: 238). The eclectic-incorporative approach is the development and enrichment of Philosophy of Pancasila National Education from various elements of foreign educational philosophy which is suitably appropriate and not contradicting with the national personality we are developing, which is released from the base of the flow system or philosophy is concerned, and further included in the structure of Philosophy of Pancasila National Education, or in other words the basics is replaced to found in Pancasila, and be made as related matters in the structure of Philosophy of Pancasila National Education. Harmony means forming a pleasing or consistent whole (Eugene Ehrlich, et al, 1986: 399) and dynamic means strength to produce a fast and fully enthusiastic movement. The process of eclectic-incorporative-harmony is done with dialectic-anticipative-reflective-rejuvenative so that the implementation of Philosophy of Pancasila National Education is always laden with novel creativity that would answer the challenges from time to time.

Dialectic comes from Greek words "dia" and "legein", which mean discourse (Dagobert D. Runes, 1974: 78) or the art of conversation (Rolan Hall, 1967: 385). in ancient Greek period, dialectic refers to a form of thinking process that is carried out through questions and answers (Ted Honderich, 1995: 198). Dialectic means an attempt to discover the truth about something using critical reasoning ... (David Stewart \& H. Gene Blocher, 1992: 850. This approach is fundamental in underlying the discovery of truth or reality.

Anticipative means being responsive to what is coming to take progressive action; reflective, self-contemplation means to uphold the intellectual clarity and moral responsibility; rejuvenative, meaning rejuvenation of the faith, the concept and implementation of the national education philosophy of Pancasila. Educational expertise based on the use of foreign systems, streams, philosophy, theory, teaching, practical education, especially the ones in which the unitary relationship does not exist or not providing knowledge that can be generalized, unanimity, unity, but knowledge about the parts or educational problems that only stand on their own that have no relations to other parts, may lead a split among education experts, which consequently will risk the students as well as the nation. On the other hand, the purpose of education, according to Ki Hadjar Dewantara (2004: 472) is physical and spiritual comprehensiveness or perfection as the only goal to be achieved to ensure a safe and happy human life, and its existence should be pursued seriously. The purpose of education is to create an ideal image of Indonesian people.

\section{Problem Statement}

Pancasila view of the fact of reality, human, knowledge and values implies that education aims to develop students' potential to become human beings who are faithful, virtuous, healthy, knowledgeable, kretif and become citizens of a democratic and accountable. Thus a system of philosophy, theory, teaching, practice Pancasila national education should be arranged so that a single policy for solving the problems of national education, and developing human ideal image of Indonesia.

National education philosophy Pancasila has the position and function as providing guidance and objectives, giving deepening, essence, basis, draft to be primary, while the use of the systems and teachings come from outside after integrated with the national education system is only as helpers, comparison, enrichment, and in others indirect role is secondary. Thus be solved possibilities like splitting education experts, who in time could give the impression to the students (Indonesian people) with a substantial risk for the formation of national identity.

\section{Purpose of Study}

The purpose of the study is to conclude Indonesian Human Ideal Image in the Philosophical Constructs of Pancasila National Education, namely construct Indonesian National Education Philosophy, which is expected to be a reference estuary in the formation of Indonesian Man. Philosophical Constructs of Pancasila National Education will be dynamically contextual frame theory development efforts, national education systems and 
praxis, and also as a reference solving national education issues from a philosophical point.

\section{Methodology}

This type of study is a philosophical study, namely hermeneutical philosophical studies. The subjects of this study are the works of "founding fathers" (especially Bung Karno) of Pancasila, and the works of Ki Hajar Dewantara, Notonagoro and Driyarkara about the philosophy of Pancasila, and on national education, as well as dialogue with the works of other relevant figures, and reflect on the various national education issues that are philosophical. The method of study used is dialectical hermeneutics. Data analysis of this study used hermeneutic dialectic approach (Fig. Madison, 1988: 29-30) whose elements are as follows: (1). Coherence, (2) comprehension, (3) penetration, (4) accuracy, (5) feasibility, (6) contextualization, (7) Synthesis, and (6) Suggestive. In the dialectic (dialogue) between the researcher (interpreter) with the philosophy of Pancasila material works "founding fathers" (especially Bung Karno), 1945, the work of major figures ("great mind approach") education (Ki Hajar Dewantara, Notonagoro, and Driyarkara) that has to do with the philosophy of education philosophy of Pancasila and nationality be open, transformative, participatory and productive, in realizing the "fusion of horizons of meaning" in reaching the truth.

\section{Results and Discussions}

\subsection{Urgency Pancasila as the Basic Philosophy of Indonesian Nation}

Indonesian society is a pluralistic society. The principle of Unity in Diversity (Bhinneka Tunggal Ika) was proposed by Bung Karno after Indonesia's independence. The beauty of pluralism is reflected in Bung Karno's motto: Let jasmine and ylang and rose and chrysolite, and all flowers bloom together in the garden of Indonesia (Speech Bung Karno, August 17, 1964). Pluralism should be understood as "genuine engagement of diversities within the bonds of civility" (Nurcholish Madjid, 1999). Therefore it is not worthy for beauty to be tainted. From our own experience and from our own history grows something else of teaching the Communist Manifesto or Declaration of Independence., Something that is much more appropriate, something that is much more suited called Pancasila. Yes Pancasila or Five Pillars of our country (Sukarno, 2000: 54-57). Bung Karno in a speech on June 1, 1945 BPUPKI propose Pancasila as the basic philosophy, "philosofische grondslag", "Weltanschaung", which was established in the State of Indonesia (Sukarno, 1964: 19-34) is known as a digger Pancasila. Although Pancasila is the property of Indonesia, which is extracted from the "down to earth personality of Indonesian nation" does not mean the ideals embodied in the principles of Pancasila are fully practiced in life. To practice as a whole the values of Pancasila is ideal so that the image of the ideal man woke Indonesia has a national education strategic role.

He also asserted that three-quarters of the Earth's surface, has been explored, even visited various countries, including countries that his people are Muslims. Bung Karno increasingly feel proud that Pancasila basis state that is the basis of the country that is admired by almost all the nations he has visited, particularly by Muslims (Sukarno, 1990: 57). It is only logical that Bung Karno with a fiery spirit figures very persistent in socializing prowess Pancasila.

The events of late that clearly prove otherwise on the basis of Pancasila we split, proving clearly that only Pancasila can still condemn our country, still save our country. Our country needs unity and that Pancasila is but one Weltanschauung is a means of unifying the people of Indonesia that is colorful (Sukarno, 1964: 65). Without state Pancasila Indonesia would disintegrate without any sense of Indonesian nationhood strap in efforts to achieve the goals and ideals of Indonesian nationhood in a peaceful orderly life dynamic frame between nations.

\subsection{Ideal Indonesian Humanity}

As unique human beings, which has the potential psychiatric to know everything, namely his existency, his potential, his life, his duty, the objectives to be achieved include the ultimate goal of existence, not surprisingly, has been born and developed science that many (Imam Barnadib, 2002: 3 ). Education means that a man was seen as an effort to improve the position and existence to enlightenment of humanity. Image of the ideal man is a man that Pancasila Indonesia. The nature of the human image of Indonesia's Pancasila can be found and are reflected from the view of the above figures; it can be formulated as follows, namely:

\subsubsection{First, Unity of Organized Harmony Dynamic Body (Physical)-Soul (Spiritual)}

Unity of Organized Harmony Dynamic Body (Physical)-Soul (Spiritual) consists of: (1). Body (physical) and can support a healthy soul activity creative, innovative and productive based on moral values-spiritual sublime accordance with religious values and the values of Pancasila became the desire of the Indonesian human education. In the context of religious education and education in the Pancasila can strengthen each other and form a religious man berpancasila. And Pancasila has been agreed it should open the door for the entry of the 
widest beam revelation (religion), so the accusation that Indonesia based on Pancasila is not different from the secular state can be resisted (Syafii Ahmad, 2009: 196) let alone the first principle of Pancasila is belief in the Almighty God, the religious meaning; (2). Soul (spiritual): has a "differentiation" forces by Ki Hajar Dewantara called "tri-sakti", namely mind, feeling and volition or "your-taste-intention", which by Notonagoro termed sense-think-will. Sense is drawn to the fact / truth, feeling drawn to the beauty of the psyche and the will drawn to the goodness. The integration of these three forms of power, and in the light of religion will clear the soul and its manifestation.

\subsubsection{Having Nature of Moral (Susila) Humanity}

The maning of 'susila' according to Notonagoro is moral conformity with human nature to do the deeds at the instigation of the will, based on reasonable judgment, in harmony with the taste and needs of human beings and human nature as individuals and social beings so fully owned pious nature, which is intangible: (1) Wisdom or penghati care, (2) Courage (3) simplicity and (4) Justice is all to achieve the goal of human life is absolute, perfect happiness is (Notonagoro). Susila by Ki Hajar Dewantara (2004: 483) diertikan as human refinement. Expertise, intelligence, and science, all may not be ignored, but more likely not be ignored is the "human decency and perfect". Without moral, a man cannot attain democracy, there is a regular state, there is a healthy economy, there can be no higher technique used for shared prosperity (Driyarkara, 2006: 350-351), so it will bring lost to individual, society, nation and state. Human decency is the human way of thinking, the way it feels and the way the act is always based on the values upheld by the community, the nation and humanity.

\subsubsection{Have the Ability or Expertise}

Have the ability or expertise in accordance with the occupied areas in the community, in the context in local, national and global. Capability is "the quality that makes an action or process possible, the capacity or power to do something" (Eugene Ehrlich, et.al, 1980: 4). While the skills and expertise can be translated as high skills in a particular field. Indonesian human future that has the ability / expertise, have the following characteristics: (1). "Well informed" (all-knowing), (2). "Life-long learning" (lifelong learning), (3). integrative and conceptual thinking, (4). react quickly, with "response-time" short, (5). rational reasoning, and (6). be creative-innovative-anticipatory (Soedjatmoko, 1991: 97-98), (g). think clearly and positively, (h). and open to criticism.

\subsubsection{Having Indonesian Personality}

Pervin \& John stated that the personal characteristics of personality show consistent patterns that explain feelings, thoughts and behavior (Estonian Hayu Purnamaningsih, 2011: 94) especially funder said differences in temperament, disposition or character (Estonian Hayu Purnamaningsih, 2011: 94). Attributes of a race for the most part are created by his experiences, namely history. But it is also determined by the ideals of the nation. Human life is choosing her sari. In pilihanlah a man and a nation embody the whole personality. In the meantime each option adds on experience, and the way his personality was so changed. In the extreme choice and Futurity combined, and in the selection, manifested and growing personality (Soedjatmoko, 1986: 31) in the face of current challenges of time or challenge the socio-cultural changes more quickly.

Based from the discussions, we arrive at these conclusions: first, the dynamic nature of understanding national identity, and second, the importance of the element in a nation's desire to understand himself, and the third raise as much as possible and develop our creativity as a nation (Soedjatmoko, 1986: 31). Therefore the personalized, possessing the properties: (1). responsible bold, (2). sensitive to social justice and social solidarity, national and mankind, (3). sensitive to the tolerance limits of society, (4). own self-esteem and self-confidence, a strong faith, (5). organize and work together with other persons or parties, whether national or international scalable, then cultural differences, religion or race, (6). menalar morally (moral reasoning or ijtihad) and have the ability to interpret the provisions on religion until terungkapkan relevance to problems and new developments (Soedjatmoko, 1991: 98-99)

According to Notonagoro is personality of nation, namely personality of Indonesia is the number of unit fixed features is attached to the nation and people of Indonesia, the features of human nature and the nature of the specific nature, which led the nation of Indonesia and Indonesian people as yourself, as a person apart from other nations and other nations as well as distinct from other nations (Notonagoro, 1980: 84) so that the identity of the Indonesian people. Therefore, if we call personality of Indonesia is Pancasila personality, it actually has meaning that we remain in our personality of nature, but in the concrete realization of the dynamic we have, we actually have to form a new embodiment of our personality that according to the demand situation, the possibility of and age, with the remains conscious and loyal to the personal nature of our (Notonagoro, 1980: 95) which has a specific ideals. 
Personality of nation as a whole is determined by the nationality of the citizens keperibadian, but personality of nationality of the residents are also determined by personality of Nations (Driyarkara, 2006). In short, called personality of nation that is not something that is static or not be realized by the experiences they had done before, but in continuous history is dynamic, namely also determined by the ideals of his day, and his ability to give new answers, which is not contained in long deposition on new issues. So this is thanks to the culture of a nation's ability to grow and repair themselves (Soedjatmoko, 2001: 63-64). personality of nation is a national identity that is dynamic in its development, consisting of individual citizens are honest, patient, humble, discipline, responsibility, self-respect attitude, creative, cooperative, visionary, love people and love of the land water, has integrity, and sincere in doing good, it should always be informed by the values of the precepts of Pancasila. It requires citizens of the nation have insights, attitudes and behaviors that are consistent in practice and securing the values principles of Pancasila which includes the first principle on God (religious), the second pillar of a just and civilized humanity (humanist), the third precept unity of Indonesia (nationality), fourth principle democracy guided by the inner wisdom of deliberations / representative (democratic), and the five precepts of social justice for all Indonesian people (fair) in an organic unity, harmony, dynamic.

\subsection{Position of the Philosophy of Pancasila National Education}

The position of national educational philosophy, educational theory nationality, national education teaching and educational practices of each nationality in different hierarchical views of the level of depth, moving from the most in the national education philosophy namely, somewhat less than it namely national educational theory, and to the most namely less in national education and teaching new national education practices. Notonagoro describe the position of the national education philosophy as the author received from his lectures in the National Education Theory courses Pancasila. Of course, the authors feel as stock is very valuable in looking to the future of education in Indonesia. Hierarchy of knowledge about the national education writer gets acquired during the National Educational Theory lectures on Pancasila, Notonagoro directly from the Institute of Education Sciences in the Faculty of Teacher Training and Education Yogyakarta. Diagram of knowledge about education by berikuti Notonagoro is illustrated in the Figure 1 below.

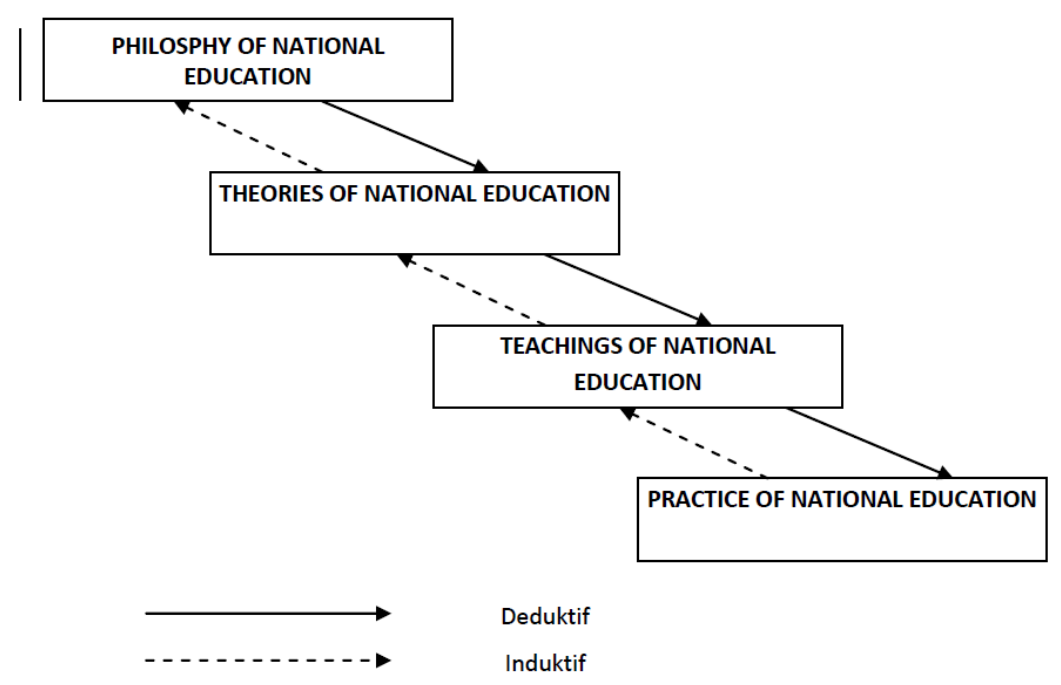

Figure 1. Knowledge of education hierarchies

Figure 2 is adapted from Wolgang Brezinka (1992: 35) below sight line Notonagoro as already stated above. 


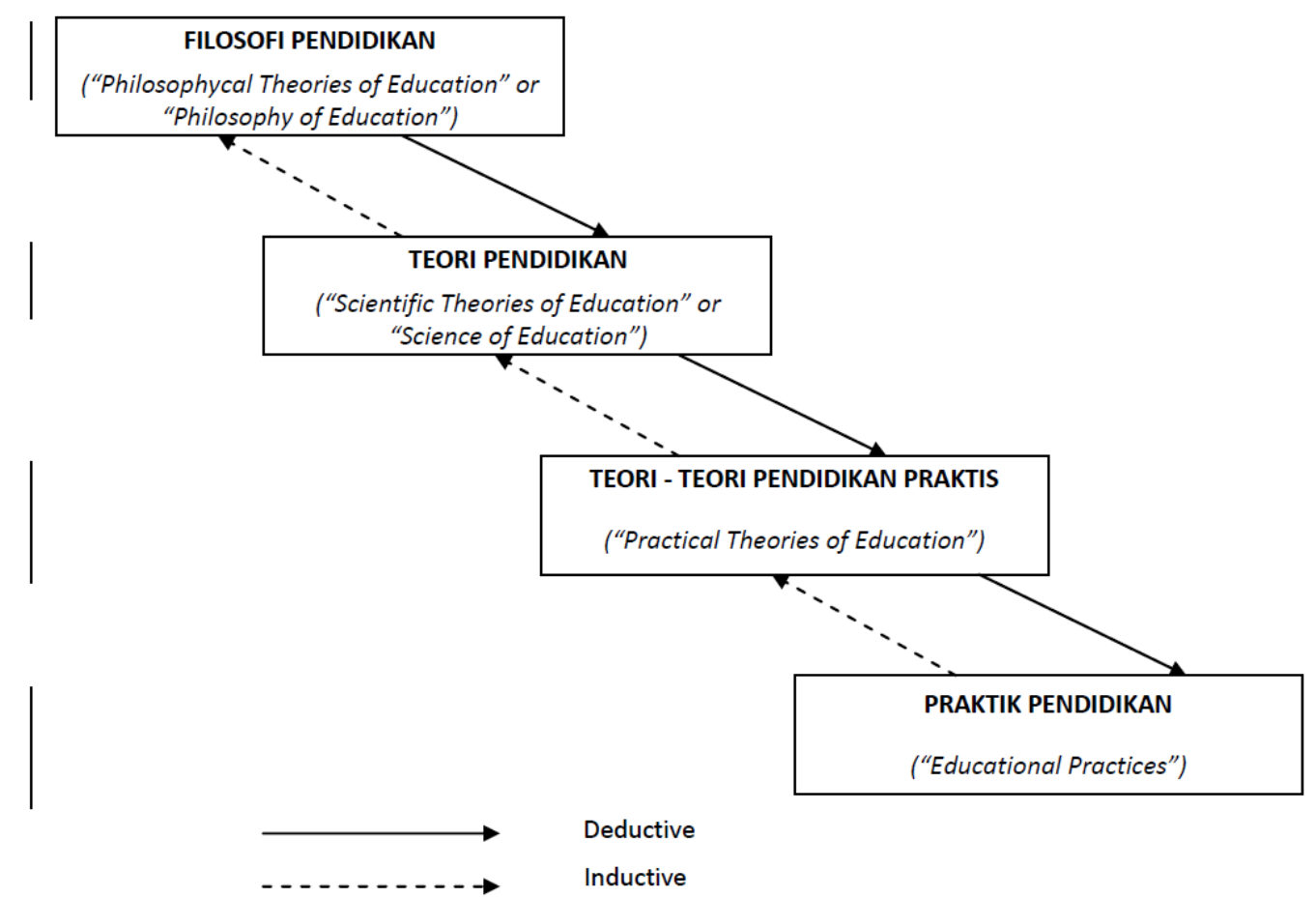

Figure 2. Knowledge of education hierarchies

Philosophy of Pancasila National Education can be said able to determine the root of the robustness of Indonesian national education system. From these roots will flow the essence of national education that can nourish and steps will guide the development of education theory and praxis of nationality, so that education held no bias and spawned beings Indonesia's Pancasila. Ironically, however, until now there has been no attempt by the government to formulate a national education philosophy constructs (construct national education philosophy Pancasila). Bustle of educational reform undertaken to date are still partial, technically, "borrowing" and reactive, less examine first the roots of the problem so that the national education foundations essential in a comprehensive national educational issues integral untouched.

The philosophy of education is the adoption of a philosophical analysis of the field of education (Imam Barnadib, 1994: 14) to answer the problems of philosophical education. Philosophy of Pancasila National Education is the philosophical analysis of the application of national education to respond to the problems of national education philosophical nature. While the theory says that it has honorific appellation status, it is a word often used but rarely defined in the literature of education, similar to the word practice. Theory, in reality consists of the concepts are arranged in logical (Barnadib \& Sutari Imam Imam Barnadib, 1996). In etimologis, according to the theory means something that is "found" in mind, plan, meaning that good, suggestion or a systematic view of a field study (survey).

Philosophy of Pancasila National Education is a systematic or coherent thoughts about national education. While the National Education teaching Pancasila can be defined as a set of national educational regulations regarding compiled or made by an authorized person or body, and have a binding force for the maintenance of national education. Notonagoro, give examples of the teachings of Education with the statutory existence in the national education are imperative, means should be implemented. Therefore must be implemented, then the legislation organizing to be done in a fair education by using two approaches simultaneously, the deductive approach and inductive approach critically dialektis done as a dynamic harmonious union. Clarification of terms used in the legislation is required in academic education possible, so that legislation can be said to be structured in juridical scientific.

The practice is similar to the theory which is said a lot but is very rarely defined. It is the possibility of people whom already know their own view of what is meant by the two terms. Said practice can be defined as how to implement what is in theory. Oxford American Dictionary pronounces it as practicable "to carry out in action, to do something habitually" (Eugene Ehrlich et al, 1986: 700). Practice often falls behind the theory. Generally point to a practical performance, actions or actions based on familiarity, art, or strategies. 
National Education practice Pancasila is a system performance, action or activity in the implementation of the national education system maintenance Indonesia who always firmly based and epitomized by the national education philosophy of Pancasila, the national educational theory and teaching Pancasila in creating national education goals. National education philosophy is firmly based on the philosophy of Pancasila Pancasila.

Noeng Muhadjir also presents a reflective approach to the study of the importance of deductive-inductive, ie the intelligent mind and empirical sensitivity, so that the results achieved can always actual and anticipatory (Noeng Muhadjir, 2011: 5) in developing nations morals or self esteem. Education as part of the moral culture always in the frame, for education (including teaching) is a "moral enterprise". While John Dewey (2007) warned that "instruction as the means of education", and education, said Frederick Mayer (Dwi Siswoyo, 2013) "as a process leading to the Enlightenment of Mankind".

RM. Hutchins (Dwi Siswoyo, 2013), as has been discussed earlier, states that the education system is intended "to dramatically improved man as a man", in order to be truly human. Humanization is important as some of us are still at a low level of civilization, which is reflected in the attitude of humanity. Technology, able to attend Dehumanization impact, so rehumanization effort cannot be ignored. Without possession of the national education philosophy Pancasila construct a platform and mold the "blue-print" of implementation, expansion and reform of the national education system, the education system will mis-orientation and ex-directors. In this context, efforts to develop national education philosophy Pancasila construct is a very important point.

\section{Implications and Recommendations}

The findings of the study prove that the national education philosophy of Pancasila as a platform for the implementation, expansion and improvement of the national educational system. Indonesian citizens are expected to adopt Pancasila values of scale, especially in education. Educators have a role to be a good example for students and learners are able to develop into individuals who have the freedom and opportunity to learn independently. In addition, the adoption of Pancasila values can also be used in methods of teaching. Educational methods used by teachers to consider the purpose of education to be achieved and student-centered active learning.

\section{Conclusions}

In conclusion, the Indonesian people should always fight continues in revitalizing, reinnovate, reconstruct, and re-actualize Pancasila in society, nation and state. Ideal image of Indonesian people is true to Pancasila, a man who behaves religiously, a humanist, and upholds democratic values of justice in organized harmonious dynamic, healthy physical-spiritual union, as a moral man, and the abilities/ skills and personality of Indonesian who can implement and develop in an orderly and peaceful life in meetings and interactions with each other and the world. Philosophical Constructs of Pancasila National Education, the Philosophy of Pancasila National Education, as a platform and resource base for the Indonesian national education, in creating an ideal image of Indonesian people.

\section{References}

Barnadib, I. (1994). Educational philosophy: system and method (Filsafat pendidikan: sistem dan Kaedah). Yogyakarta: Penerbit Andi Offset.

Brezinka, W. (1992). Philosophy of Educational Knowledge. Dordrecht: Kluwer Academic Publishers. http://dx.doi.org/10.1007/978-94-011-2586-4

Dewantara, K. H. (2004). Synthesis of Ki Hadjar's work: Part One Education (Karya ki Hadjar Dewantara: Bagian Pertama Pendidikan). Yogyakarta: MLPTS.

Driyarkara. (2006). Driyarkar's complete work (Karya Lengkap Driyarkara; Edited by A. Sudiarja dkk). Jakarta: PT. Gramedia Pustaka Utama.

Ehrlich et al. (1986). Oxford American Dictionary. New york: Avon Books.

Kamus Besar Bahasa Indonnesia (KBBI). (2012). Jakarta: Debdikbud.

Kneller, G. F. (1971). Introduction to the Philosophy of education. New York: John Wiley \& Sons, Inc.

Lipsitz, J. (1995). Prologue : Why We Should Care About Caring. McCombs, Barbara L. \& Whisler.

Ma'arif, A. S. (2009). Ground points in a journey, an autobiography. Bandung: Mizan Publishers cooperation and Maarif institute (Titik-titik kisar di perjalananku, autobiograf. Bandung: Penerbit kerjasama Mizan dan Maarif institute) 
Madison, G. B. (1988). The hermeneutics of postmodernity. Bloomington \& Indianapolis: Indiana University Press.

Madjid, N. (1999). Scholars \& religiosity society: The columns in tabloid determination, Jakarta: Tabloid Cooperation determination and Publisher Paramadina (Cendekiawan \& religiusitas masyarakat: Kolom-kolom di tabloid tekad, Jakarta: Kerjasama Tabloid Tekad dan Penerbit Paramadina).

Muhadjir, N. (2000). Educational and Social Change (5th ed.). Yogyakarta : Penerbit Rake Sarasin.

Runes, D. (1974). Dictionary of Philosophy. New Jersey: Littlefield Adams \& Co.

Sastrapratedja, M. (2001). Education as humanization (Pendidikan sebagai Humanisasi). Yogyakarta: Universitas Sanata Dharma Yogyakarta.

Siswoyo, D. (2013). Developing a science education for enlightened humanity. In D. Siswoyo (Ed.), Education for enlightenment \& independence of the nation. Yogyakarta: Faculty of Educational Studies State University of Yogyakarta.

Soedjatmoko. (1985). Liberation ethics (Etika Pembebasan). Jakarta: LP3ES.

Soedjatmoko. (1986). Human dimension in development (Dimensi manusia dalam pembangunan). Jakarta: LP3ES.

Soedjatmoko. (1991). Soedjatmoko and future concerns (Soedjatmoko dan keprihatinan masa depan). Yogyakarta: PT. Tiara Wacana.

Sue, J. (1997). The Learner-Centered Classroom and School. San Francisco: Jossey-Bass Publishers.

Sukarno. (1964). Identify Pancasila: Pancasila State philosophy policy. Jakarta: Ministry of Information RI. (Camkan Pancasila: Pancasila dasar falsafah Negara. Jakarta: Departemen Penerangan RI.)

Sukarno. (1990). Bung Karno and Islam. Jakarta: Penerbit CV MasAgung.

\section{Copyrights}

Copyright for this article is retained by the author(s), with first publication rights granted to the journal.

This is an open-access article distributed under the terms and conditions of the Creative Commons Attribution license (http://creativecommons.org/licenses/by/3.0/). 